\title{
Do Balkan Countries Have a European Future? An Analysis of Real Economic Convergence, 1989-2005
}

\author{
Jalal El Ouardighi , Rabija Somun-Kapetanovic
}

\begin{abstract}
The purpose of this paper is to assess the economic performance of Balkan countries compared to the European Union over the period 1989-2005. We use three economic indicators of income, productivity and employment. The analysis rests on the test of the real convergence process of these indicators. The results show evidence of real convergence (i.e., convergence hypothesis and reduction of inequalities) of labour productivity in Balkans, but they are mixed for income per capita and employment rate. The development gap between the Balkans and the European Union, which has widened considerably in the 1991-1993 period, shows a sign of recovery after this date. However, the gap remains very deep and the process of catching up with the European Union is too slow.
\end{abstract}

Key words: Convergence, Balkan Countries, Statistical Framework

JEL : C23, 040, 052

DOI: $10.2478 / \mathrm{v} 10033-007-0002-4$

\section{Introduction}

The difficult question of a European future for the five countries in the Balkans (Albania, Bosnia-Herzegovina, Croatia, Macedonia and Serbia-Montenegro) has lately received more attention from the European commission (e.g., Thessaloniki and Brussels reunions, 2003). There is considerable consensus that the future of Balkan countries is in the European Union (EU). In order to prepare for their accession to the EU, the process of "stabilization and association" constitutes the principal instrument of the European policies with respect to these countries. In fact, the European future of the Western Balkan countries relies on their capacity to carry out reforms in their political, economic and social domains and to accomplish the pre-defined accession criteria. However, it remains unclear whether integration depends entirely on the success of reforms undertaken by the candidate countries or on the willingness of the EU to set off a timely and successful integration with regard to the specifics of each country. While Europe is comprised of very heterogeneous areas, it deplores significant gaps in development. Real convergence, which would allow a reduction of economic inequalities between countries, remains a crucial question (see Treaty of Maastricht). This is an issue not only
*Jalal EL OUARDIGHI : Bureau d'Economie Theorique et Appliquee - BETA - Theme. Pôle Européen de Gestion et d'Economie - PEGE. Université Louis Pasteur - ULP, Strasbourg I. 61, Avenue de la Foret Noire F-67085 Strasbourg Cedex, France. Tel : (33) 0390242079 - Fax: (33) 03902420 71. e-mail : jalal@cournot.u-strasbg.fr.

*Rabija SOMUN-KAPETANOVIC ( corresponding author ) : Faculty of Economics in Sarajevo.

Trg Oslobodenja 1, 71000 Sarajevo, Bosnia and Herzegovina. Tel : (387) 33275925 - Fax. (387) 33 2759 94. e-mail: rabija.somun@efsa.unsa.ba. 
for the present member countries of the EU, but also within the context of the Union's enlargement eastwards. Consequently, the test of the existence of a real convergence process across countries may represent a significant contribution to economic analysis. It can also have important implications not only for national policies, but also for the European actions mainly channeled through cohesion and structural funds.

In this paper, we do not claim to have an answer to the question of the European future of the Balkans. We wish, rather, to highlight the development gaps between the Balkans and EU countries. Our study included analysis of the economic performance captured by three indicators of income (GDP per capita), labour productivity (GDP per person engaged) and employment rate (person engaged per population) between 1989 and 2005. Two concepts of real convergence have been analyzed, i.e. the $\beta$-convergence (convergence hypothesis) and the $\sigma$-convergence (reduction of inequalities). Our findings show evidence of real convergence of labour productivity in Balkans. However, the evidence of GDP per capita and employment rate convergence is mixed. Furthermore, the comparative analysis of Balkan economic performances relative to the EU-27 shows that the development gaps are very important, although the recovery started since 1991/1993 and there is a weak convergence process of income and labour productivity in EU-27.

The paper is organized as follows. Section 2 reviews briefly the theoretical aspects of the convergence process, which are mainly used in growth literature. Section 3 describes and analyzes the data of Balkan economic indicators. Section 4 presents an empirical analysis of real convergence and discusses the estimation results of convergence equations. Section 5 summarizes the main conclusions from the convergence process in Balkan countries.

\section{The Concepts of Convergence}

The popular approaches which are used to test the convergence process explore the concepts of $\beta$-convergence (absolute or conditional on a set of controlling variables) and $\sigma$-convergence. The former implies that the poor countries grow faster than the richer ones (i.e. convergence hypothesis) and the latter measures the reduction of dispersion of income within a sample of countries (see Barro and Sala-i-Martin 1995). The two concepts are complementary measures of real convergence, because $\beta$-convergence is a necessary condition but not sufficient for $\sigma$-convergence (see Sala-i-Martin 1996a). Absolute convergence rests on the hypothesis of the neo-classical theory. Assuming that the technologies are identical and exogenous, the convergence process relies on diminishing returns of capita, the factor most responsible for the recovery of countries lagging behind (Solow 1956). Under these circumstances, economic policy does not have an impact on long-term growth. However, the new endogenous growth theory does not predict that absolute convergence is the rule. Countries approach different steady-states depending on several structural factors, such as human capital (Lucas 1988), R\&D efforts (Romer 1990), among others. In this context, government policy can positively affect long-term growth through economic incentives.

The $\beta$-convergence has been applied in numerous papers since the pioneering study of Baumol (1986) on the OECD countries. The majority of evidence suggests that convergence is conditional where physical and human capital accumulation, innovation and investment are found to be the most significant conditioning factors (e.g., Levine and Renelt 1992; De la Fuente 1997; Temple 1999; Islam 1995, 2003). This approach, however, suffers from serious econometric pitfalls (Galton's fallacy), as pointed out by Friedman (1992) and Quah (1993). Hence, the o-convergence is a supplementary test applied in many papers. But while a diminution in the dispersion is evidence of convergence, it does not offer a test of the convergence hypothesis, i.e., an economy with income (or productivity) lagging behind other economies has a potential to grow faster. Even so, the two concepts provide insight into real convergence and must be analyzed jointly. This is precisely what we will do in the next sections.

\section{Data and Statistical Framework}

Our empirical investigations examine the evolution of the GDP per capita (GDP/population), labour productivity (GDP/Employment) and employment rate (Employment/population) of five Balkan countries over the period of 1989-2005. We will also highlight the situation of these Balkan countries relative to EU countries. The data used are extracted from the Groningen Growth and Development Center database (GGDC 2007). The series of the GDP are expressed in PPPs (Purchasing Power Parities) in US dollars with constant prices in 1990. The use of the data in PPPs is 
an approach which proves to be more adapted to the international comparisons of countries' economic performance (Maddison 2001, 2005). Table 1 summarizes the average levels and growth rates of economic indicators by country in the period of 1989-2005. The results show considerable differences between countries. Indeed, Croatia has 2.6 times larger per capita GDP (165\%) and labour productivity (152\%) than Albania (64\% and 58\% respectively). BosniaHerzegovina ranks second with 108\% for GDP per capita and $135 \%$ for labour productivity compared to the Balkan average. With respect to employment rate, the disparities are least marked and all countries are located around the average level. The comparative performance of GDP per capita and labour productivity is also differentiated. BosniaHerzegovina records the highest average annual increases in labour productivity (6.3\%) and in GDP per capita (2.6\%). Consequently, it caught up with most of its delay compared to Croatia. Albania ranks second, with $4.4 \%$ and $2.1 \%$ average annual rates of labour productivity and income per capita, respectively. In contrast, Serbia-Montenegro and, to a lesser extent, Macedonia experienced greater falls in GDP per capita $(-4.1 \%$ and $-1.5 \%)$ and in labour productivity ($1.6 \%$ and $-0.8 \%)$. Finally, the decline in employment rate is rather general and ranged on average between $-0.6 \%$ per year (in Croatia) and $-3.7 \%$ per year (in Bosnia-Herzegovina)

Table 2 presents the Balkan situation relative to EU-27. The average levels of GDP per capita, labour productivity and employment rate are respectively about 28\%, 42\% and

\begin{tabular}{|c|c|c|c|c|c|c|}
\hline \multirow[b]{2}{*}{ COUNTRY } & \multicolumn{2}{|c|}{$\begin{array}{l}\text { GDP / } \\
\text { capita }\end{array}$} & \multicolumn{2}{|c|}{$\begin{array}{c}\text { GDP / } \\
\text { Employment }\end{array}$} & \multicolumn{2}{|c|}{$\begin{array}{l}\text { Employment/ } \\
\text { Population }\end{array}$} \\
\hline & 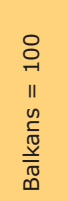 & 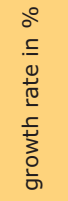 & 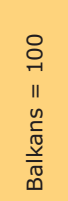 & 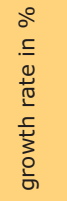 & 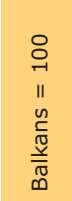 & 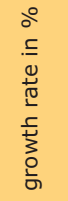 \\
\hline Albania & 64 & 2.1 & 58 & 4.4 & 106 & -2.3 \\
\hline Bosnia and Herzegovina & 108 & 2.6 & 135 & 6.3 & 85 & -3.7 \\
\hline Croatia & 165 & 0.0 & 152 & 0.6 & 104 & -0.6 \\
\hline Macedonia & 88 & -1.5 & 90 & -0.8 & 93 & -0.7 \\
\hline Serbia and Montetnegro & 76 & -4.1 & 64 & -1.6 & 113 & -2.4 \\
\hline ALL & 100 & -0.1 & 100 & 1.6 & 100 & -2.0 \\
\hline
\end{tabular}

\section{Table 1:}

Economic Indicators of Balkan Countries, average 1989-2005

Notes: GGDC Database and author's calculation. GDP is expressed in \$ with constant prices of 1990, person engaged for Employment.
70\% the EU-27 levels. The Table 2 shows that the relative decrease in per capita GDP (-2.2\%) and employment rate $(-2 \%)$ was larger than that of labour productivity $(-0.2 \%)$. It is interesting to underline that the majority of the relative decline took place in the 1989-1993 period for GDP per capita and during the period 1989-1991 for labour productivity. A slower recovery started in 1991/1993 for labour productivity and income (see Figure 1), whereas the employment rate continued to decline, except the slight rebound observed between 1993 and 1998. But as Figure 1 shows, the economic indicator levels of 2005 remain still lower than those observed in 1989.

\begin{tabular}{|c|c|c|c|c|c|c|}
\hline \multirow[b]{2}{*}{ COUNTRY } & \multicolumn{2}{|c|}{$\begin{array}{l}\text { GDP / } \\
\text { capita }\end{array}$} & \multicolumn{2}{|c|}{$\begin{array}{c}\text { GDP / } \\
\text { Employment }\end{array}$} & \multicolumn{2}{|c|}{$\begin{array}{l}\text { Employment/ } \\
\text { Population }\end{array}$} \\
\hline & 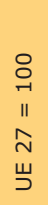 & 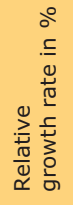 & 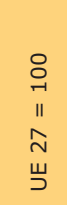 & 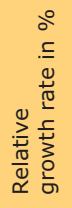 & $\begin{array}{l}\text { О } \\
\stackrel{-1}{1} \\
\| \\
\stackrel{N}{ } \\
山 \\
ٍ\end{array}$ & 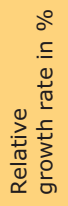 \\
\hline Albania & 18 & 0,1 & 25 & 2.6 & 74 & -2.3 \\
\hline Bosnia and Herzegovina & 30 & 0,6 & 57 & 4.5 & 60 & -3.7 \\
\hline Croatia & 46 & -2.0 & 64 & -1.2 & 72 & -0.6 \\
\hline Macedonia & 24 & -3.5 & 38 & -2.6 & 64 & -0.7 \\
\hline Serbia and Montetnegro & 22 & -6.1 & 27 & -3.5 & 79 & -2.4 \\
\hline ALL & 28 & -2.2 & 42 & -0.2 & 70 & -2.0 \\
\hline
\end{tabular}

\section{Table 2.}

Economic Indicators of Balkan Countries:

European Union $=100$, average 1989-2005

Notes: GGDC Database and author's calculation. GDP is expressed in \$ with constant prices of 1990, person engaged for Employment.

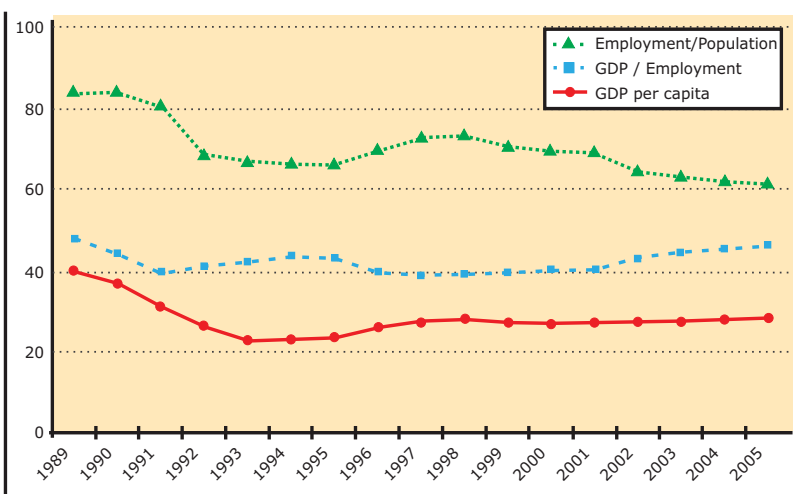

Figure 1.

Economic Indicators of Balkan Countries, EU27 $=100$.

A more disaggregated view on each of the five Balkan countries reconfirms the same kind of evidence mentioned above but with different realities (see Figures 2, 3 and 4). Figure 2 compares trends in GDP per capita. After a col- 
lapse during the period of 1989-1993, the average relative income level of Bosnia-Herzegovina recovered and slightly exceeded the 1989 level in 2005. Albania has reached the 1989 level in 2005. Croatia experienced a slow recovery that started in 1993 but it has not reached its 1989 level yet. For Macedonia and Serbia-Montenegro, no significant recovery was detected. We can make the same reports as before by examining comparative trends in labour productivity (see Figure 3), except the fact that the recovery is more signifi-

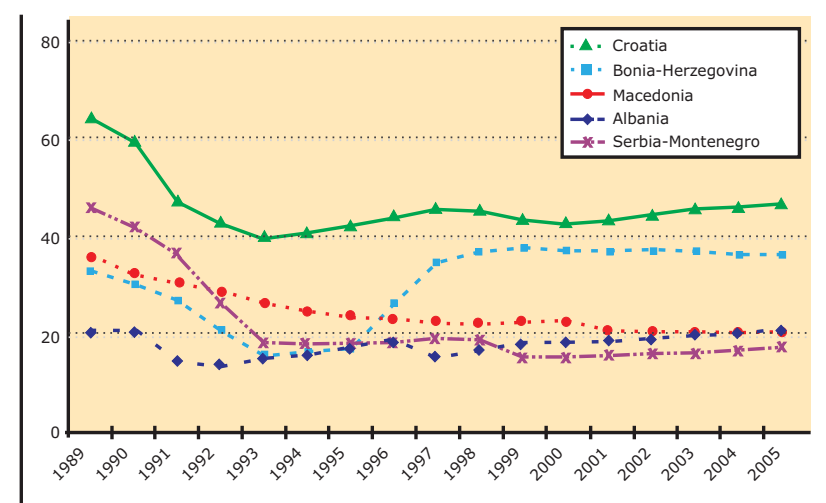

Figure 2.

GDP per capita, EU27 $=100$.

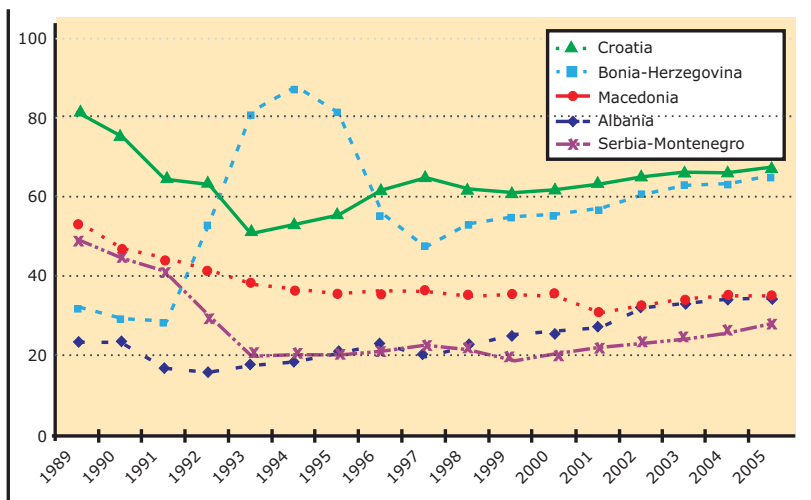

Figure 3.

Labour Productivity : GDP per person engaged, $\mathrm{EU} 27=100$.

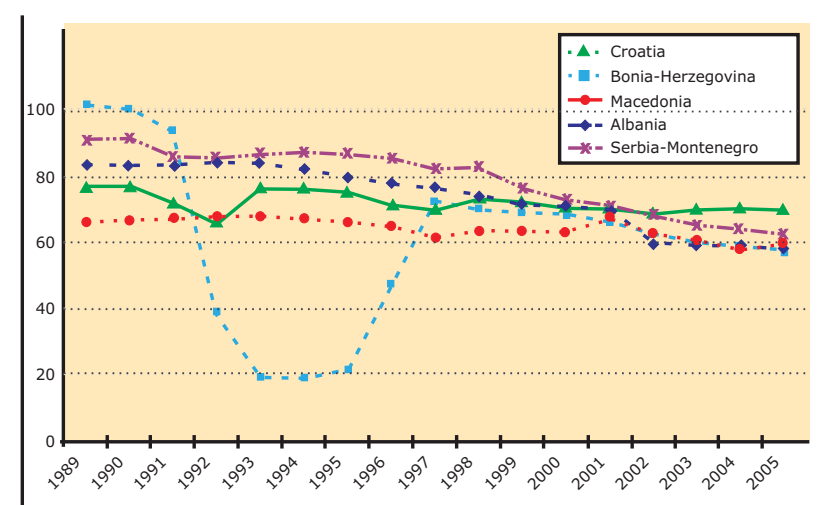

Figure 4.

Employment Rate : person engaged per population, $\mathrm{EU} 27=100$ cant for all countries, excluding Macedonia. Finally, we can observe a continuous decline in the employment rate since 1989 (see Figure 4). This implies all Balkan countries and the 2005 employment rate levels are very close.

\section{Empirical Evidence on Convergence}

\subsection{The Trends of Inequalities}

The concept of $\sigma$-convergence implies a reduction in the inequalities of an economic indicator (e.g., income, productivity, etc.) within a sample of countries. Several measures can be considered to capture these inequalities (see Cowell and Jenkins 1995; Cowell 1995). In convergence literature, it is common to use the standard deviation or the coefficient of variation (standard deviation devised by the variable mean) to collect these inequalities. In this study, we chose the Theil index (Theil 1967) given that its properties are additive and decomposable (see Shorrocks 1984). Let $\gamma_{i t}$ be an economic indicator of country $i(i=1, K, n)$ at time $t$ $(t=1, K, T)$. We can define the Theil index as the sum of contributions of each country to the global inequality of $\gamma_{i t}$ :

Theil_index $x_{t}=\sum_{t=1}^{n}$ Cineq $_{i t} \quad, \quad$ Theil_index $\in[0 ; \ln (n)]$

where Cineq $_{i t}$ is the contribution to global inequality of country $i$ at time $t$ defined by the following expression:

$$
\text { Cineq }_{i t}=\frac{y_{i t}}{n \bar{y}_{* t}} \ln \left(\frac{y_{i t}}{\bar{y}_{* t}}\right), \quad \bar{y}_{* t}=\frac{1}{n} \sum_{i-1}^{n} y_{i t}
$$

where In is the natural-logarithm. Table 3 presents the inequalities indicators in the Balkan countries. As can be seen, the GDP per capita inequality reveals an upward trend. The Theil index grew at $0.8 \%$ per year on average between 1989 and 2005. In contrast, the labour productivity and employment rate inequalities declined respectively at $2.1 \%$ and $7.9 \%$ per year on average. These results show clearly a $\sigma$ - divergence process of GDP per capita and a $\sigma$ - convergence of labour productivity and of employment rate (see Figure 5). In a disaggregated view, the contributions to the total inequalities of GDP per capita and labour productivity (see Table 3 ) are positive on average in Bosnia-Herzegovina (0.024 and 0.093 respectively) and Croatia (0.165 and 0.129 respectively). Furthermore, Bosnia-Herzegovina experienced a higher increase of contributions to inequalities of GDP per capita and labour productivity with respectively $7.6 \%$ and $16.7 \%$ average annual growth rates. In contrast, the fall of contributions to global inequality is recorded in 
Serbia-Montenegro (-6.8\% for GDP per capita and $-3.6 \%$ for labour productivity) and in Macedonia $(-2.1 \%$ and $-4.1 \%$ respectively). With respect to employment rate, the levels of contributions to global inequality are very close and range between 0.029 in Serbia-Montenegro and -0.016 in BosniaHerzegovina. Nevertheless, we can underline the highest progression (13.5\% per year on average) of Bosnia-Herzegovina's contributions to employment rate inequality.

\begin{tabular}{|c|c|c|c|c|c|c|}
\hline \multirow[b]{2}{*}{ COUNTRY } & \multicolumn{2}{|c|}{$\begin{array}{l}\text { GDP / } \\
\text { capita }\end{array}$} & \multicolumn{2}{|c|}{$\begin{array}{c}\text { GDP / } \\
\text { Employment }\end{array}$} & \multicolumn{2}{|c|}{$\begin{array}{c}\text { Employment/ } \\
\text { Population }\end{array}$} \\
\hline & 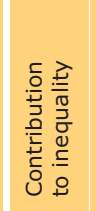 & 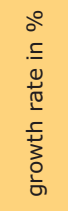 & 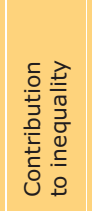 & 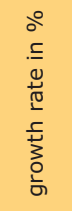 & 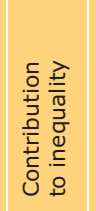 & 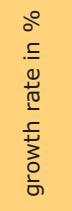 \\
\hline Albania & -0.056 & 6.0 & -0.060 & 7.1 & 0.013 & -0.1 \\
\hline Bosnia and Herzegovina & 0.024 & 7.6 & 0.093 & 16.7 & -0.016 & 13.5 \\
\hline Croatia & 0.165 & 0.5 & 0.129 & -1.0 & 0.008 & 3.4 \\
\hline Macedonia & -0.021 & -2.1 & -0.017 & -4.1 & -0.014 & 3.2 \\
\hline Serbia and Montetnegro & -0.037 & -6.8 & -0.052 & -3.6 & 0.029 & -0.4 \\
\hline ALL & 0.075 & 0.8 & 0.093 & -2.1 & 0.021 & $-7,9$ \\
\hline
\end{tabular}

\section{Table 3.}

Inequality Indicators of Balkan Countries, average 1989-2005

Notes: GGDC Database and author's calculation.

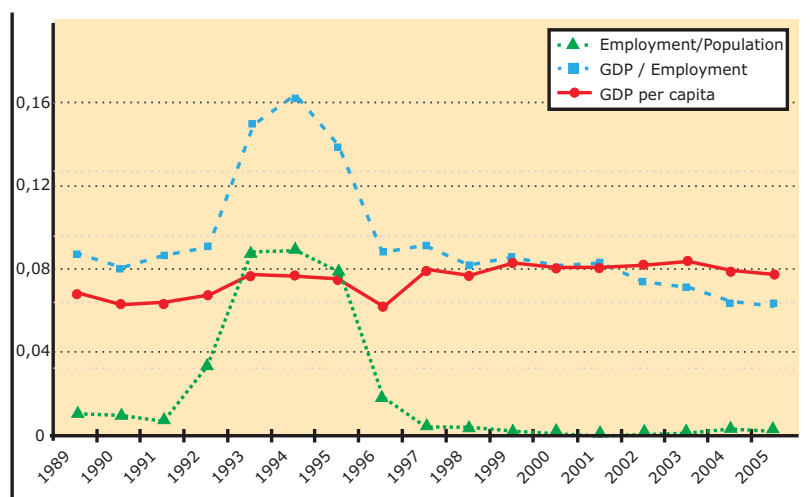

Figure 5.

Inequality of Economic Indicators, Balkan Countries

In a comparative analysis including several groups of countries, the decomposition property of the Theil indicator allows for distinction of 'between-group' and 'within-group' inequalities. The between-group inequalities index is defined as the sum of contributions of each group of countries to global inequality:

$$
\text { Theil_index } x_{t B}=\sum_{j=1}^{m} \text { CBineq }_{j t}, \quad j=1, \mathrm{~K}, m,
$$

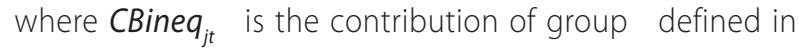
the same manner as in equation (2) and by substituting $Y_{j t}$ to $\gamma_{i t}$. The decomposition of the Theil index (see Table 4) shows that the inequalities between the Balkans and EU-27 account on average for $28 \%$ of total inequalities in labour productivity, 36\% in GDP per capita and $44 \%$ in employment rate. The progression rates of between-inequalities are particularly higher for GDP per capita (+2.9\% per year) and employment rate $(+11.9 \%$ par year). Figure 6 compares trends of inequalities between Balkan and EU-27 countries. It may be observed that the largest increase of income inequalities between the two groups was realized in the period of 1989-1993. The inequality of labour productivity slightly increased in 1989/1991 but at the same time has not declined much since 1991.

\begin{tabular}{|c|c|c|c|c|c|c|}
\hline \multirow[b]{2}{*}{ COUNTRY } & \multicolumn{2}{|c|}{$\begin{array}{l}\text { GDP / } \\
\text { capita }\end{array}$} & \multicolumn{2}{|c|}{$\begin{array}{c}\text { GDP / } \\
\text { Employment }\end{array}$} & \multicolumn{2}{|c|}{$\begin{array}{c}\text { Employment/ } \\
\text { Population }\end{array}$} \\
\hline & 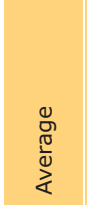 & 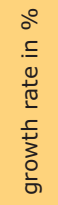 & $\begin{array}{l}0 \\
\frac{0}{\pi} \\
\frac{0}{\omega} \\
\stackrel{\alpha}{\alpha}\end{array}$ & 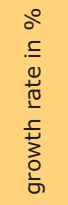 & $\begin{array}{l}0 \\
0 \\
\frac{\pi}{0} \\
\frac{0}{\|} \\
\gtrless\end{array}$ & 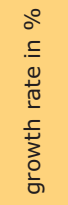 \\
\hline Between - Theil index & 0.057 & 2.9 & 0.032 & 0.5 & 0.007 & 11.9 \\
\hline share & $36 \%$ & 1.2 & $28 \%$ & 1.5 & $44 \%$ & 8.9 \\
\hline Eu27 - Theil index & 0.101 & 1.0 & 0.118 & -1.1 & 0.017 & 2.9 \\
\hline
\end{tabular}

\section{Table 4:}

Inequality Indicators: Balkan Countries versus EU27, 1989-2005 Notes: GGDC Database and author's calculation.

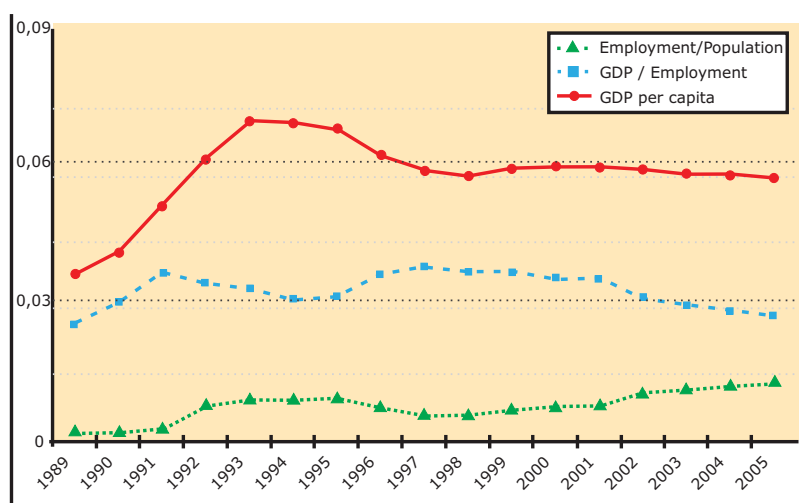

Figure 6.

Inequality of Economic Indicators,Balkans versus EU27

\subsection{Test of Convergence Hypothesis}

The index Theil_index _ captures the level of the total inequality at any time $t$. The slowdown of the index collects the $\sigma$-convergence process, but it does not support the convergence hypothesis. Thus, it's necessary to supplement 
the analysis by examining the $\sigma$-convergence process. In order to test this last, we considered the theoretical framework on the convergence of the economies. One may refer to Barro and Sala-i-Martin (1995) or Islam (1995) for the analytical development to derive the convergence equation from production function. In particular, the empirical approaches rest largely on the reduced following equation:

$$
\ln y_{i t}=\bar{c}+\beta \ln y_{i 0}+X_{i t}^{\prime} \gamma+u_{i t},
$$

where $\gamma_{i t}$ is the GDP per capita (or labour productivity) of country $\mathrm{i}(i=1, K, n)$ at time $\mathrm{t}(t=1, K, T)$, and $\gamma_{i 0}$ is its initial value. The error term $u_{i t}$ captures the effects of the omitted variables that are peculiar to both country and time. $X_{i t}$ is a vector of exogenous variables which determines the individual equilibrium level of countries. The constant term $c$ is a function of the steady-state assumed to be constant. The condition that $\beta<1$ implies a convergence process, with the speed of convergence equal to $(-1 / T) \ln (\beta)$

Within the framework of modeling at an international level, the choice of explanatory variables ( ) is strictly limited by the availability of data across countries and over time. Among the relevant factors, it is wise to consider the variables already used in the studies on the conditional convergence (see Dowrick and Nguyen 1989; Mankiw, Romer and Weil 1992; Barro and Sala-i-Martin 1992; Sala-i-Martin 1994, 1996b; De La Fuente, 1997). Levine and Renelt (1992) list no less than 15 variables used in the literature on economic growth. However, the authors conclude that convergence continues to be robust with the investment and the initial value of income, while other variables lose their significance (e.g., population growth, monetary and tax-related variables, etc.).

In this paper, we limited our objective to identifying the economic performance of Balkan countries compared to EU countries. Thus, on the one hand, we considered the Balkan dummies in the list of explanatory variables. This enabled us to take account of the difference in the equilibrium levels. On the other hand, we assumed that varies across the two groups of countries, i.e. we supposed that Balkan and EU countries approach various steady-states but at varying speeds. In order to compare the EU-27 and Balkan convergence speeds, we made the parameter of the convergence dependent on a dummy-group variable. Finally, as the previous Figures showed, two phases were identified, 19891993 and 1994-2005. The first period was characterized by a collapse in per capita income and labour productivity in all countries. The decline is dramatically significant in the Bal- kans due to the conflicts which marked this region. Taking this situation into account, we incorporated into the model a temporal dummy for the first period and 0 otherwise. All things considered, the estimates specification is in the following form:

$$
\ln y_{i t}=\bar{c}+\beta_{i t} \ln y_{i 0}+\gamma_{1} D_{j}+\gamma_{2} T_{t}+u_{i t} \quad, \quad \beta_{i t}=\alpha_{0}+\alpha_{1} D_{j}+\alpha_{2} T_{t} .
$$

where $D_{j}=1$ if $j=$ Balkans and $T_{t}=1$ for $t=1989-1993$

\subsection{The Estimation Results}

The method of estimation of equation (5) must take into account the structure of the error term $U_{i t}$. If $U_{i t}$ is composed of a country and time specific effects, the OLS (Ordinary least squares) method is not appropriate and the two situations must be considered. The first one assumes that the specific effects are fixed. In this case, we can use the 'within' estimator by applying OLS to the specification in terms of deviations from means of variables. However, the transformation 'within' eliminates the effects but also all time-invariant and individual-invariant variables. The second method assumes that the specific effects are random. In this case, the GLS (Generalized Least Squares) provides efficient estimators and allows for the identification of all structural parameters (see Baltagi 2001). Even so, it should be emphasised that if the effects are correlated with the explanatory variables, GLS is not recommended. Although for $N$ and $T$ large the GLS and within estimators are asymptotically equivalent. Moreover, in the semi-asymptotic case, GLS remains efficient than the within estimator (see Matyas 1995).

The GLS estimations of the equation (5) using data from the 32 countries (i.e., $27 \mathrm{EU}$ and 5 Balkan countries) over the period 1989-2005 are presented in Table 5. As can be seen in Table 5, we estimated successively the convergence equation for GDP par capita, labour productivity and employment rate. The results give evidence of convergence of per capita GDP and labour productivity in the Balkans. Moreover, our findings show that the speed of convergence is significantly higher for labour productivity than GDP per capita. It appears also that the speed of convergence of labour productivity in the first sub-period 1989-1993 (3.5\%) is lower than in the second sub-period 1994-2005 (4.6\%). However, the situation is reversed in the case of GDP per capita, where the speed of convergence loses 0.4 points between the first and second sub-periods. On average it could take 32 years to eliminate half of the Balkan countries' differences in GDP per capita, but only 15 years to do so in the case of labour productivity. It is noteworthy that our 
results do not suggest any convergence process in the case of EU countries. The speeds of convergence are negative and rather indicate a trend of persistence. With respect to employment rate convergence, the results are reversed. The parameter of convergence is still negative for Balkan countries and does not suggest any convergence process. While in the case of the EU, the results show a clear convergence process of $2.4 \%$ convergence speed in the first sub-period and of $5.7 \%$ in the second sub-period. Furthermore, our estimations indicate that the country variability (country-effect variance/ sum of all variances) represents respectively $34 \%, 48 \%$ and $54 \%$ of the total variability of employment,

\begin{tabular}{|c|c|c|c|}
\hline Equation & $\begin{array}{l}\text { GDP / } \\
\text { capita }\end{array}$ & $\begin{array}{c}\text { GDP / } \\
\text { Employment }\end{array}$ & $\begin{array}{c}\text { Employment/ } \\
\text { Population }\end{array}$ \\
\hline Constant & $\begin{array}{c}-1.453^{*} \\
(0.639)\end{array}$ & $\begin{array}{r}0.085 \\
(0.701)\end{array}$ & $\begin{array}{r}-0.552 * * \\
(0.098)\end{array}$ \\
\hline In $\left(y_{i 0}\right)$ & $\begin{array}{r}1.169 * * \\
(0.074)\end{array}$ & $\begin{array}{r}1.008 * * \\
(0.069)\end{array}$ & $\begin{array}{r}0.381 * * \\
(0.119)\end{array}$ \\
\hline In $\left(y_{i 0}\right) \times$ Dummy $y_{\text {Balkans }}$ & $\begin{array}{r}-0,0456 * \\
(0.202)\end{array}$ & $\begin{array}{r}-0,554 * * \\
(0.178)\end{array}$ & $\begin{array}{r}0,287 * * \\
(0.068)\end{array}$ \\
\hline In $\left(y_{i 0}\right) \times T_{1989-93}$ & $\begin{array}{l}-0.045^{*} \\
(0.022)\end{array}$ & $\begin{array}{r}0.100 * * \\
(0.022)\end{array}$ & $\begin{array}{r}0.287^{* *} \\
(0.068)\end{array}$ \\
\hline Dummy Bsikans & $\begin{array}{c}3.912 * \\
(1.729)\end{array}$ & $\begin{array}{c}5.111 * \\
(1.699)\end{array}$ & $\begin{array}{r}-0.992 * * \\
(0,289)\end{array}$ \\
\hline $\mathrm{T}_{1989-93}$ & $\begin{array}{c}0.266^{*} \\
(0.210)\end{array}$ & $\begin{array}{r}-1.186 * * \\
(0.222)\end{array}$ & $\begin{array}{r}0.276 * * \\
(0,060)\end{array}$ \\
\hline Country effect (share) & $0.025(28 \%)$ & $0.024(54 \%)$ & $0.008(34 \%)$ \\
\hline Temporal effect (share) & $0.012(22 \%)$ & $0.007(15 \%)$ & $0.001(4 \%)$ \\
\hline Random effect (share) & $0.015(30 \%)$ & $0.014(31 \%)$ & $0.014(62 \%)$ \\
\hline SEE & 0.119 & 0,115 & 0,114 \\
\hline Observations & 544 & 544 & 544 \\
\hline \multicolumn{3}{|c|}{ Speed of convergence: period 1989-1993 } & \\
\hline EU 27 & $-0.7 \%$ & $-0.6 \%$ & $2.4 \%$ \\
\hline Balkans countries & $2.6 \%$ & $3.5 \%$ & - \\
\hline \multicolumn{3}{|c|}{ Speed of convergence: period 1994-2005 } & \\
\hline EU 27 & $-0.9 \%$ & $-0.0 \%$ & $5.7 \%$ \\
\hline Balkans countries & $2.2 \%$ & $4.6 \%$ & - \\
\hline
\end{tabular}

\section{Table 5.}

Estimation Results of Convergence Model, Balkans and EU27, 1989-2005

Notes : Random effects model and Generalized Least Squares (GLS) estimations. $\mathrm{t}=0$ in 1989. Numbers in parentheses are standard errors. $(*)$ and $(* *)$ represent statistical significance at $5 \%$ and $1 \%$ level, respectively. SEE: Standard Error of estimate. income and productivity. This suggests that the country specificities play a significant role in the convergence process, marked even more strongly when it comes to income and productivity.

\section{Concluding Remarks}

In this paper, we have conducted an exploratory approach of real convergence process across five Balkan countries in the period 1989-2005. Two concepts of real convergence were analyzed, i.e., the -convergence (convergence hypothesis) and the -convergence (reduction of inequalities). Economic performance was captured by three indicators of income, productivity and employment. The results show evidence of real convergence of labour productivity in the Balkans. Indeed, the inequality declined at 2.1\% per year between 1989 and 2005, and the speed of convergence was at 4.6\% in the period of 1994-2005. The evidence of GDP per capita and employment rate convergence is mixed. The inequality of income increases at $0.8 \%$, but convergence in GDP per capita ran at a slow annual rate confirming the basic rule of a $2 \%$ convergence rate. On the contrary, employment rate inequalities declined at $7.9 \%$ but our results do not suggest any convergence process. Furthermore, the comparative analysis of the Balkans' economic performance relative to the EU-27 show that the development gap is very significant, despite the starting recovery noted since 1991/1993 and the weakness convergence process of income and labour productivity in EU-27. Consequently, from the perspective of EU's enlargement eastwards, the European policies need to take this reality into account. The EU should support additional actions favorable to the development of the entire region of the Balkans, without further deepening of disparities among countries. It needs to define and implement common strategic development objectives for the Balkans. In the context of the Balkans' faster integration into EU, the promotion of mutual regional cooperation should be harmonised additionally. Finally, with respect to our approach, our findings are of great importance but their robustness must be analyzed, e.g., sensitivity of the results to the introduction of conditioning variables, estimation method, etc. Furthermore, numerous directions could be envisaged both at theoretical and empirical levels by analyzing more deeply the relationship between convergence and inequality. 


\section{References}

Baltagi, H.B. 2001. Econometric Analysis of Panel Data, John Wiley \& Sons.

Barro, R.J. and Sala-i-Martin, X. 1992. Convergence, Journal of Political Economy, 100, 223-251.

Barro, R.J. and Sala-i-Martin, X. 1995. Economic growth, The first MIT Press edition.

Baumol, W.J. 1986. Productivity growth, convergence, and welfare: what the Long-run data show, American Economic Review, 76(5): 1072-1085.

Cowell, F. A. 1995. Measuring Inequality, Prentice Hall, London.

Cowell, F. A. and Jenkins, S. P. 1995. How much inequality can we explain? Methodology and an application to the United States, The Economic Journal, 105(429):421-430.

De la Fuente, A. 1997. The empirics of growth and convergence: a selective review, Journal of Economic Dynamics and Control, 21, 23-73.

Dowrick, S. and Nguyen, D.T. 1989. OECD comparative economic growth 1950-85: catch-up and convergence, American Economic Review, 79, 1010-1030.

Friedman, M. 1992. Do old fallacies ever die? Journal of Economic Literature, 30(4): 2129-2132.

GGDC, 2007. The Conference Board and Groningen Growth and Development Centre, Total Economy Database, January 2007, http://www.ggdc.net.

Islam, N. 1995. Growth Empirics : A Panel Data Approach, Quarterly Journal of Economics, 110, 1127-1170.

Islam, N. 2003. What have we learnt from the convergence debate? Journal of Economic Surveys, 17, 309-362.

Levine, R. and Renelt, D. 1992. A sensitivity analysis of cross-country growth regressions, American Economic Review, 82, 942-963.

Lucas, R.E. 1988. On the mechanics of economic development, Journal of Monetary Economics, 22(1): 3-42.

Maddison, A. 2001. The World Economy: A Millennial Perspective, Paris: OECD.

Maddison, A. 2005. Growth and Interaction in the World Economy: The Roots of Modernity, Washington, D.C: The AEI Press.

Mankiw, G., Romer, D. and Weil, D. 1992. A contribution to the empirics of economic growth, Quarterly Journal of Economics, CVII, 407-437.

Quah, D. T. 1993. Galton's fallacy and tests of convergence hypothesis, Scandinavian Journal of Economics, 95, 427-443.

Romer, P.M. 1990. Endogenous technical change, Journal of Political Economy, 98(5) : S71-S102.

Sala-i-Martin, X. 1994. Cross-sectional regressions and the empirics of economic growth, European Economic Review, 38, 739-747.

Sala-i-Martin, X. 1996a. The classical approach to convergence analysis, Economic Journal, 106, 1019-1036.

Sala-i-Martin, X. 1996b. Regional cohesion: evidence and theories of regional growth and convergence, European Economic Review, 40, 1325-1352.

Matyas, L. 1995. Error components models, in Matyas, L. and Sevestre, P. (eds). The econometrics of panel data: a handbook of the theory with applications, Dordrecht: Kluwer Academic Publishers, 52-76.

Solow, R.M. 1956. A contribution to the theory of economic growth, Quarterly Journal of Economics, 70(1): 65-94.

Shorrocks, A. F. 1984. Inequality decomposition by population subgroups, Econometrica, 52(6):1369-1385.

Temple, J. 1999. The new growth evidence, Journal of Economic Literature, 37, 112-156.

Theil, H. 1967. Economics and Information Theory. North Holland, Amsterdam. 